\title{
S-CURVE DYNAMICS OF TRADE BETWEEN TURKEY AND HER TRADING PARTNERS
}

\author{
Reşat Can AKKAY
}

\begin{abstract}
The S-curve is used to describe the dynamic relation between terms of trade and trade balance. As a result of previous works the S-curve relation was obtained for some developed and developing countries within the framework of their trade with the rest of the world. On the other hand for some countries this relationship is weak or there is no relationship. The possibility of "aggregation bias" problem of the previous works leads researchers to a make the same analysis at bilateral and industry level. In our work this relationship is investigated for Turkey at aggregate level with the rest of the world, with the developing and developed countries and at the bilateral level with the 20 important trade partners for the 2003Q1-2012Q4 period. The results of our analysis for Turkey show that there is a weak S-curve relation with the rest of the world and with the developing countries. On the other hand the relation is strong with the developed countries. At the bilateral level there is a strong S-curve relation in 14 out of 20 cases.
\end{abstract}

Keywords: Terms of trade, trade balance, S-curve, J-curve

JEL Classification: F31

\section{TÜRKIYYE VE TİCARET ORTAKLARI ARASINDAKİ TİCARETİN S-EĞRİSI DİNAMİĞ}

Öz

S-eğrisi ilişkisi, dış ticaret haddi ve dış ticaret dengesi arasındaki dinamik süreci ifade etmekte kullanılmaktadır. Bazı gelişmiş ve gelișmekte olan ülkelerin tüm dünya ile ticareti çerçevesinde yapılan analizler sonucunda bu ilişkinin varlığına rastlanırken; bazı ülkeler açısından bu ilişkinin zayıf, bazı ülkeler içinse hiç olmadığı görülmektedir. Bu çalışmalarda toplulaştırma yanlılığı probleminin olma olasılığı, ülkelerin ticaret ortaklarıyla tek tek karşılıklı olarak ve endüstri kolları düzeyinde değerlendirdiği analizlerin yapılmasına neden olmuştur. Çalışmada Türkiye açısından S-eğrisi ilişkisi 2003(1)-2012(4) dönemi için tüm dünya, gelișmekte olan ülkeler, gelişmiş ülkeler ve Türkiye'nin dış ticaretindeki en önemli 20 ülke ile karşılıklı olarak ele alınmıştır. Analiz sonucunda Türkiye açısından S-eğrisi ilişkisinin tüm dünya ve grup olarak gelişmekte olan ülkeler ile zayıf; grup olarak gelişmekte olan ülkeler ile kuvvetli olduğu tespit edilmiștir. Türkiye'nin dış ticaretinde önemli olan 20 ülke ile ikili düzeyde yapılan analizin sonucunda ise S-eğrisi ilişkisinin 14 ülke için kuvvetli olduğu gözlemlenmiştir.

Anahtar Kelimeler: Ticaret hadleri, ticaret dengesi, S-eğrisi, J-eğrisi

JEL Sinıflandırması: F31

${ }^{1}$ Assist.Prof.Dr., Istanbul University, Department of Economics, canakkay@gmail.com 


\section{Introduction}

The impact of the currency depreciation on the trade balance is an empirically open question in international economics. This relation gathers around the Marshall-Lerner condition and the J-curve phenomenon in many empirical works. The Marshall-Lerner condition states that currency depreciation (devaluation) improves trade balance as long as the sum of import and export demand elasticity exceeds unity. On the other hand there have been cases in which trade balance continued to deteriorate despite the ML-condition was satisfied. (Bahmani-Oskooee, 1985:500-504) This fact led the researchers to focus on the short-run effect of the currency depreciation and on the post-depreciation (devaluation) time-path of the trade-balance which established a ground for J-Curve phenomenon. According to this approach the instant adjustment of the trade balance cannot be seen in the real trade flows because there are contract rigidities that take time to wear off and there is also time-lag that the consumers and producers take to adjust to changes in relative prices. In other words it may be trade balance deterioration in the short-run before the currency depreciation improves the trade balance in the long-run.

More recently, there has been a new concept about the relation between the trade balance and the terms of trade which was firstly introduced by Backus, Kehoe and Kydland. (Backus et al., 1994:84-103) They investigated the short-term term fluctuations in the trade balance and the terms of trade for 11 OECD countries from the perspective of a two-country stochastic growth model. They observed that the cross-correlation function for net exports and the terms of trade has an asymmetrical $\mathrm{S}$ shape in 7 of the 11 OECD countries. According to this observation the trade balance is negatively correlated with current and future movements in the terms of trade but positively correlated with past movements. (Backus et al., 1994:84) Subsequently Senhadji extended this pattern for 30 less developed countries (LDCs) and found out that the S-curve depicts the dynamic relation between terms of trade and the trade balance for LDCs fairly well. (Senhadji, 1998:128)

Graphical inspection of the cross-correlation functions in both papers indicates a weak S-curve support for some countries. This observation caused BahmaniOskooee and Ratha to focus on the potential aggregation bias problem. The main idea here was that a country's trade balance (and/or terms of trade) could be deteriorating with one trading partner while at the same time improving with another. The aggregation could smooth out the fluctuations observed in the bilateral trade. (Bahmani-Oskooee and Ratha, 2007:431) The possibility of this aggregation bias led Bahmani-Oskooee and Ratha disaggregate the data and reexamine the relation between trade balance and terms of trade on the bilateral basis. This new approach was introduced firstly with the examination of the US's trade relation with her 24 trading partners on the disaggregated data basis. The analysis indicates that the weak Scurve relation based on the aggregate data turns into a strong relation in 18 out of 24 trading partners of US at the bilateral level. (Bahmani-Oskooee and Ratha, 2007a:438-439) They investigate the same empirical regularity in the case of Ja- 
pan's bilateral trade with her 12 trading partner. According to the analysis the Sshaped bilateral cross-correlation function emerges in all cases, most notably with Canada, France, Italy, Germany, Philippines and Switzerland. (Bahmani-Oskooee and Ratha, 2007b:487-488) In 2007, Oskooee and Ratha extended the literature again through investigating the S-curve relation on the industry level basis, in more disaggregated way. In their work, 2007a, they had found excellent support for the Scurve relation on the bilateral level for US. However this support was rather weak on the level of US-UK bilateral trade. Their suspect about the possible aggregation bias led them to investigate this relation on the industry level basis. The results indicated overwhelming support for the S-curve in most of the industries. (BahmaniOskooee and Ratha, 2008:152) In 2008, Oskooee, Gelan and Ratha made the Scurve analysis for 20 African countries on aggregate level and obtained an S-curve relation in eight of 20 countries. (Bahmani-Oskooee et al., 2008:335-342). In the same year Oskooee, Kutan and Ratha investigated this relation for 10 emerging market countries on aggregate level. They found strong evidence of an S-curve in cases of Bulgaria, Crotia, Poland and Slovacia; weak evidence in cases of the Czech Republic, Hungary and Turkey; no support in cases of Cyprus, Romania and Russia. (Oskooee et al., 2008c:349-350) The lack of an S-curve pattern in the cases of Canada and US from previous work led Oskooee and Ratha to investigate the relation on industry level. As a result of the disaggregated data analysis they obtained strong support in 41 out of 60 cases. (Oskoee and Ratha, 2009:14) In 2010, Oskooee and Ratha did the same analysis for two important emerging market countries, China and India. They have found that there was no support for a S-curve relation between US and China on the aggregate level but when the data are disaggregated the results support strong relation in almost 50\% of the close to 100 industries. (Oskooee and Ratha, 2010:222) The analysis about U.S. and India indicated that the weak relationship at the aggregate data level turns into a strong S-curve relationship in 15 out of 27 industries. (Oskooee and Ratha, 2010:94) Another investigation about the Scurve dynamics of US-Hong Kong commodity trade shows that there is support for a relation in 34 out of 104 industries. (Oskooee and $\mathrm{Xu}, 2010: 127-128$ ) Oskooee and Ratha have extended the literature by providing additional evidence for disaggregated data for Sweden's bilateral S-curve relation with her 17 trading partners and by exploring US-Australia trade on industry level. The disaggregation of Sweden's trade data indicates that Sweden has a bilateral S-curve in the majority of the cases except the trade relation with Germany, Norway, UK and US. (Bahmani-Oskooee and Ratha, 2011a:358) The commodity trade data between US and Australia indicates a strong support for an S-curve relation in 89 of the 146 industries. (BahmaniOskooee and Ratha, 2011b:520-521) Oskooee has continued to explore the dynamic relationship between terms of trade and trade balance for China and Germany; for US and Mexico and for a resource rich state Azerbaijan with different researchers on commodity level basis. The work about China and Germany states that there is an Scurve relation in 22 out of 62 industries. (Oskooee and $\mathrm{Xi}, 2012: 24$ ) The same analysis for US-Mexico commodity trade indicates that the lack of the S-curve rela- 
tion at aggregate data level turns through disaggregation process into a strong relationship in 90 out of 223 industries. (Oskooee and $\mathrm{Xu}, 2013: 46-47)$ The analysis of aggregate, bilateral and industry-level about Azerbaijan supports consistent and strong evidence for a S-curve relation in each of the data segment. In other words trade balance correlates positively with the balance of trade on the aggregate, bilateral and commodity level. In 16 out of 20 industries an S-curve relation is detected. (Oskooee and Jamilov, 2013:18-19) The latest contribution to the literature investigates the dynamic S-curve relation for Central and Eastern European countries. According to the result of this work there is evidence of a S-curve pattern for Slovenia, Czech Republic, Hungary; weak support for Lithuania, Poland, Romania and Slovakia and no support for Bulgaria, Latvia and Romania. (Ferreira-Lopez and Sequire, 2014:69)

This paper investigates the same relation for Turkey's trade with her 20 trading partners in line with the existing literature. Basically the empirical part of the Scurve literature consists of the works implemented by Bahmani-Oskooee and Artatrana Ratha. Turkey has been analyzed empirically only in one of their works under the name of emerging market countries on aggregate data level. The results indicated a weak support for an S-curve relationship. (Oskooee et al., 2008c:349) As far as we know our work will be the first empirical analysis that provides some results about the S-curve relation for Turkey on both aggregate and bilateral data level. The rest of the paper is organized as follows: Section 2 defines the data, definitions and methodology. Section 3 shows the S-curve relation for Turkey in four steps. First Turkey versus the world using aggregate data, second Turkey versus industrial countries, third Turkey versus developing countries and finally the bilateral S-curves between Turkey and her 20 trading partners.

\section{Data, definitions and methodology}

Using quarterly data, Turkey and her 20 trading partners (Belgium, Bulgaria, China, France, Germany, Greece, India, Iran, Israel, Italy, Japan, Korea, Netherland, Romania, Russia, Saudi, Spain, Switzerland, UK and US) are examined over the period 2003-2013. The relative importance of the trading partners can be seen in Table 1 based on their trade shares.

The aim of the analysis is to investigate the dynamic relation between terms of trade and trade balance based on the S-curve concept at aggregate and bilateral level. In line with Backus et al.(1994:84) the terms of trade is defined as the price of imports relative price of the exports, and trade balance is defined as the net exports (X-M) over GDP (both in nominal terms). Since data on bilateral basis for Turkey with her trading partners are not available, (the inverse of) the real bilateral exchange rate has been used as a proxy for the bilateral terms of trade following existing literature. Bilateral terms of trade is represented by the calculating the real bilateral exchange rate, defined as , where is the CPI in country A, is the CPI in Turkey and is the nominal exchange rate defined as 
Table 1: Turkey's Trade Shares With Her Trading Partners 2012

\begin{tabular}{lccc}
\hline Trading partner (i) & Export(millions of dollar) & Import(millions of dollar) & Trade share \\
\hline Germany & 13126,3 & 21400,2 & 0,089 \\
Russia & 6682,1 & 26625,3 & 0,086 \\
China & 2833,2 & 21295,2 & 0,062 \\
Iran & 9922,0 & 11964,8 & 0,056 \\
U.S. & 5605,3 & 14130,4 & 0,051 \\
Italy & 6374,1 & 13344,5 & 0,051 \\
France & 6199,1 & 8589,9 & 0,038 \\
UK & 8695,7 & 5629,4 & 0,037 \\
Spain & 3719,0 & 6023,6 & 0,025 \\
Netherland & 3247,5 & 3660,6 & 0,018 \\
India & 791,7 & 5843,6 & 0,017 \\
Switzerland & 2124,6 & 4304,9 & 0,017 \\
South Korea & 528,0 & 5660,1 & 0,016 \\
Belgium & 2359,8 & 3690,3 & 0,016 \\
Saudi Arabia & 3677,0 & 2171,1 & 0,015 \\
Romania & 2496,5 & 3236,4 & 0,015 \\
Greece & 1401,8 & 3539,9 & 0,013 \\
Bulgaria & 1681,6 & 2753,8 & 0,011 \\
Israel & 2329,8 & 1710,4 & 0,010 \\
Japan & 332,0 & 3601,4 & 0,010 \\
\hline
\end{tabular}

Note: together these 20 countries accounted for $65 \%$ of Turkey's trade with the rest of the world

the number of country A's currency per Turkish Lira. According to this definition, an increase in the real bilateral exchange rate reflects a real depreciation of Turkish Lira. The data have been detrended using the Hodrick-Prescott filter with smoothing parameter $=100$. (Senhadji, 1998:108) The computation of the lead and lag correlations of the detrended series has been calculated and plotted for negative lags and positive leads. The perfect S-curve relation can be described as an asymmetric crosscorrelation function which indicates positive relation for positive lags (leads) and negative relation for negative lags.

\section{The cross-correlation functions}

In this section the cross-correlation functions between terms of trade and trade balance will be examined for different cases of Turkey's trade at aggregate and bilateral level. Following previous works the existence of a potential aggregation bias problem is one of the main concerns of this paper too. Therefore two sets of S-curves will be presented according to the degree of disaggregation. The first set includes the S-curve relation of Turkey's terms of trade and trade balance with the rest of the world; with developed countries and with developing countries as a group. The second set includes various S-curve relations with the 20 trading partners of Turkey on bilateral level. 
The inspection of the Turkish trade data in Fig 1 and Fig 2 indicates a weak S-curve relation with the rest of the world and with the developed countries. On the other hand there is evidence for an S-curve relation in Fig 3 with the developing countries. Fig 4 presents the graphical inspection of the bilateral S-curves between Turkey and her 20 trading partners. The examination indicates bilateral S-curve relations in the majority of the cases. Especially this relation is strong with trade partners China, India, Italy, Iran, Israel, Greece, Netherland, Romania and Spain. In the cases of Belgium, France, Russia, UK and US there is also evidence for S-curve but relatively weaker than the previous countries. On the other hand there is no evidence for an S-curve in the cases of Turkey's trade with Germany, Japan, Korea, Saudi Arabia, Switzerland and Bulgaria.

Fig 1: Turkey's Trade With the Rest of the World

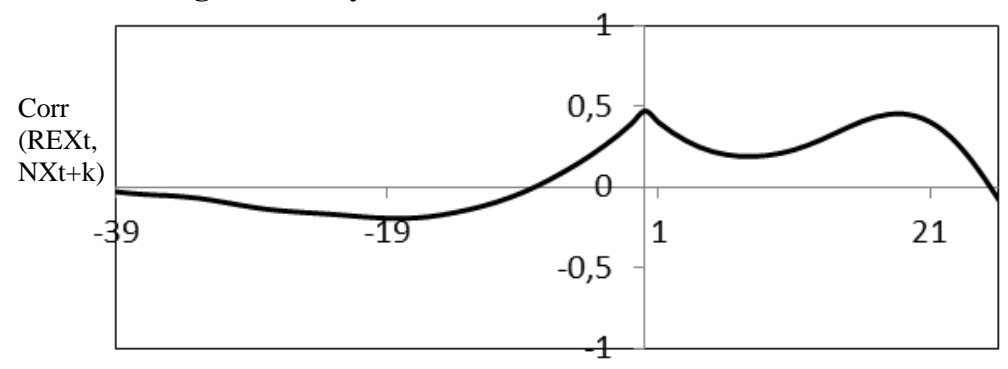

Fig 2: Turkey's Trade With the Developed Countries

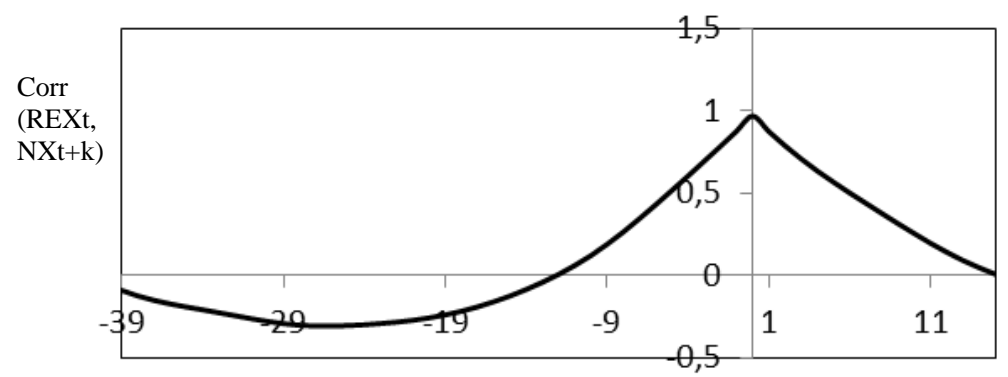


Fig 3: Turkey's trade with developing countries

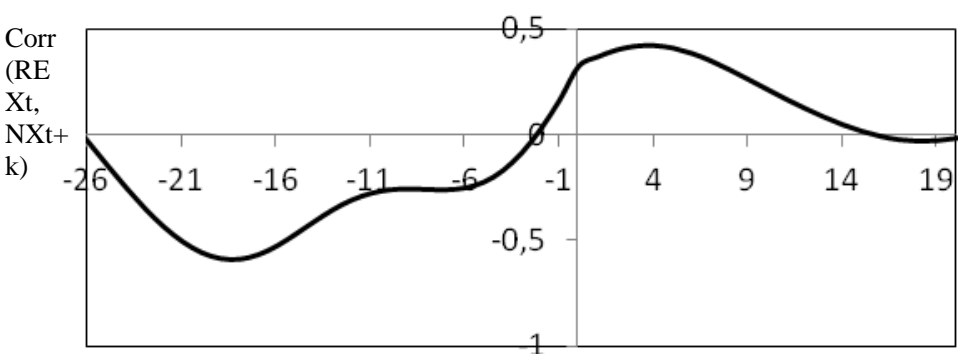

Fig 4: The Bilateral S-Curve of Turkey
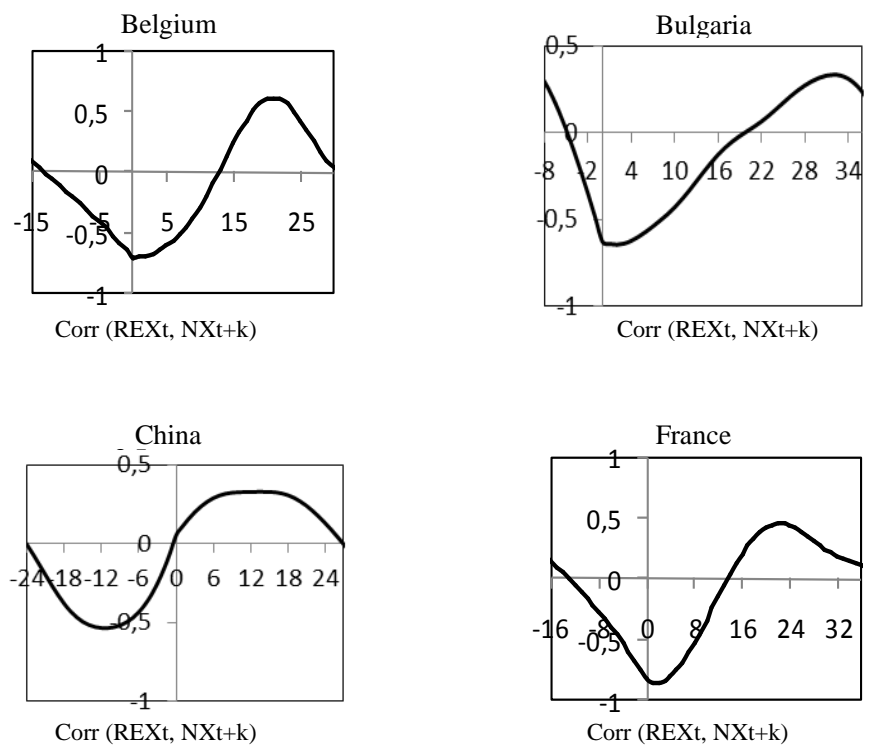


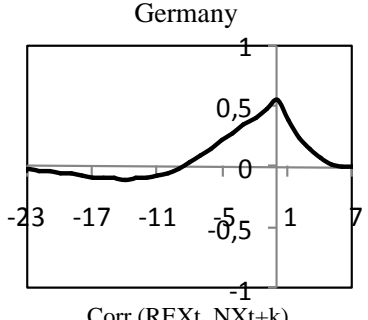

Corr (REXt, NXt+k)

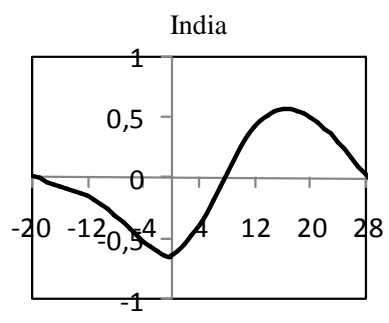

Corr (REXt, NXt+k)

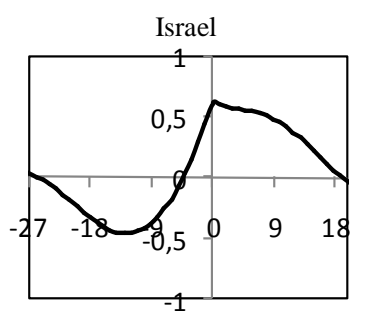

Corr (REXt. NXt+k)

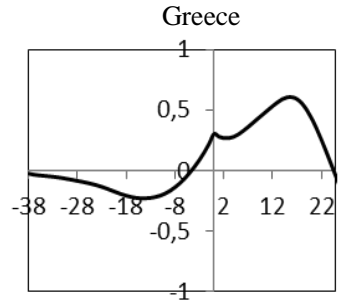

Corr (REXt, NXt+k)

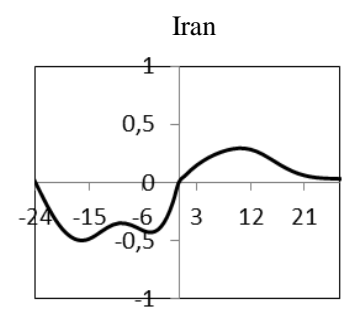

Corr (REXt, NXt+k)

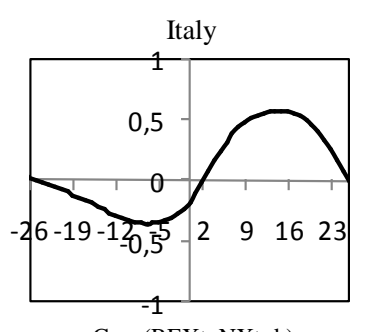

Corr (REXt, NXt+k) 

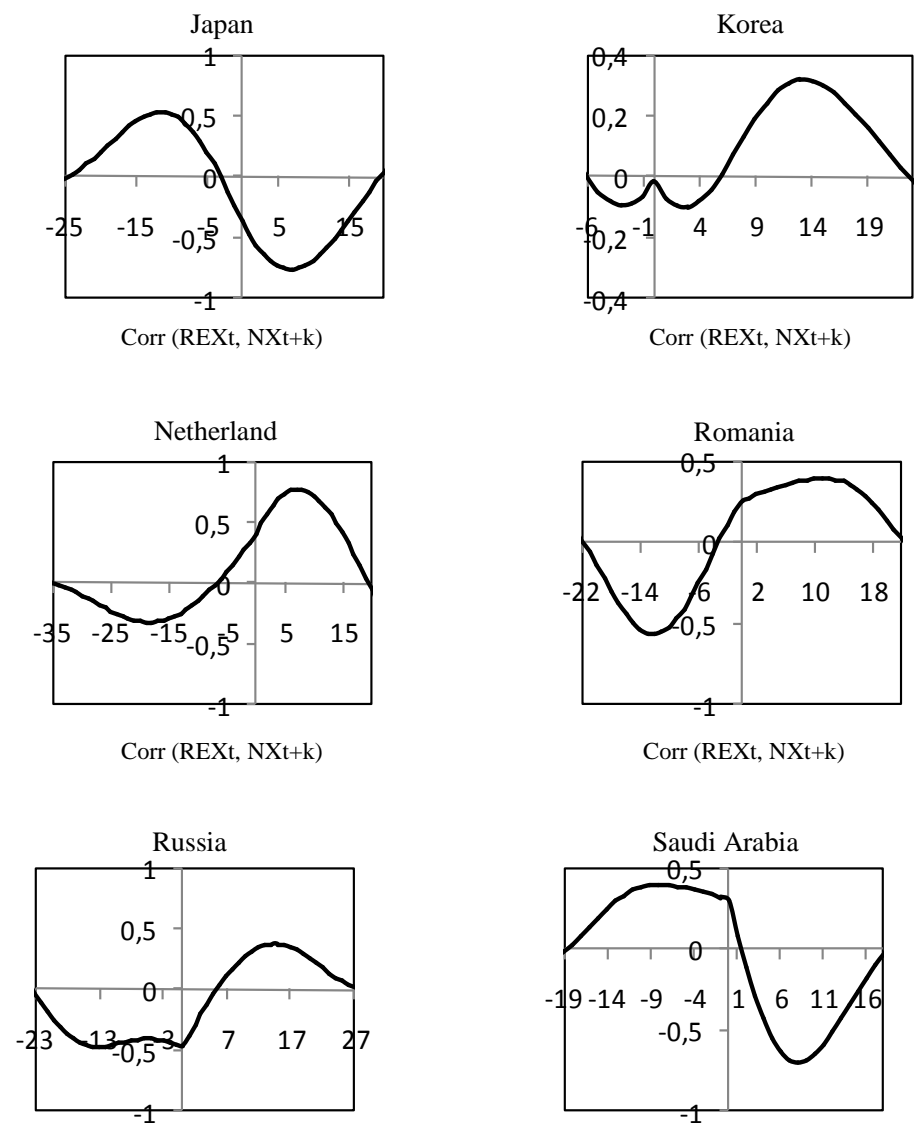

Corr (REXt, NXt+k)

Corr (REXt, NXt+k)
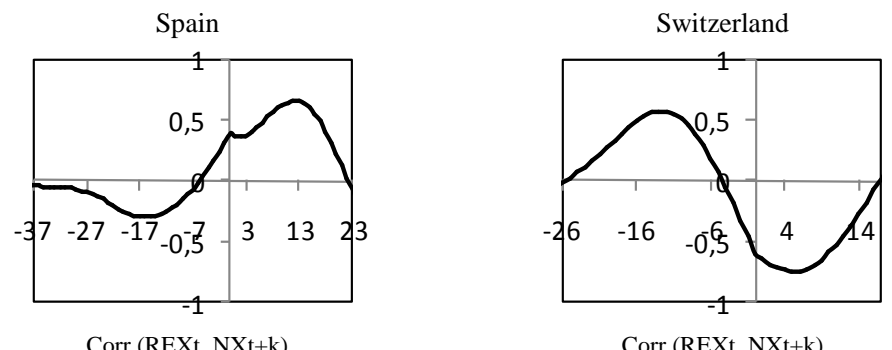

Corr (REXt, NXt+k) 

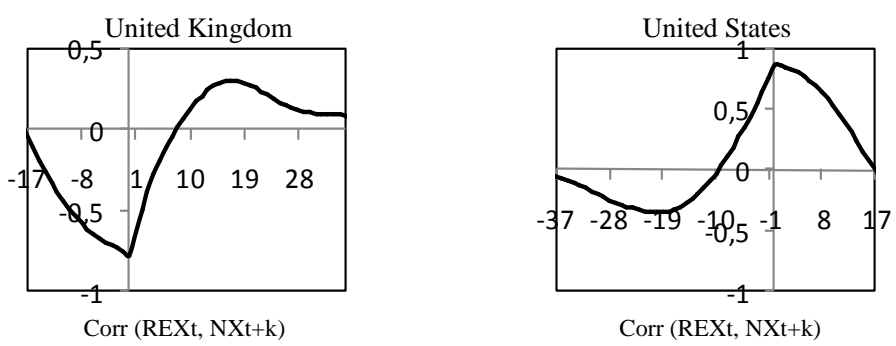

\section{Conclusion}

Backus et al. (1994) introduced a new way for analyzing the relation between terms of trade and trade balance which is called as S-curve relation. This concept is based on the horizontal S-curve which exists as a result of the graphically presentation of the past and future correlations of these two series. This finding was also supported by the work of Senhadji who confirmed this pattern for most of the developing countries. Bahmani-Oskooee and Ratha extended the literature by disaggregating the trade data and investigating the S-curve relation first at bilateral then at industry level. The examination of trade at bilateral level showed that the lack of the S-curve relation at aggregate data level gives place to a strong S-curve relation when the data are disaggregated. The analysis at industry level indicated the more the data is disaggregated the more obvious is the S-Curve relation. In line with the existing literature the same analysis was conducted in this paper for Turkey's trade with her 20 trading partners by using quarterly data between the years 2003-2013. The analysis at aggregate level exerts no support for an S-curve relation with the rest of the world and with the developed countries. On the other hand there is support for an Scurve relation with the developing countries. In order to overcome the possible aggregation problem the Turkish trade data was disaggregated and the result of the analysis shows an S-shaped bilateral cross-correlation function in 14 out of 20 cases.

The result is consistent with the existing literature at both aggregate and bilateral data level but on the other hand some questions about the S-curve relation remained unanswered. The cross-correlation functions show us that in some countries or in some industries the response of the trade balance is fast but in most of the cases it is slow. The causes of the differences in the adjustment speeds among countries and industries seem an interesting research area. As a second point the adjustment process before and after the exchange rate depreciation (devaluation) is in most of the cases too long to suggest a policy recommendation to suggest an exchange rate policy. Therefore almost the conclusion part of all works in the existing literature tells us only about the percentage of a strong or weak S-curve relation. 


\section{References}

BACKUS, D.K., KAHOE, P.J. and KYDLAND, F.E. (1994), "Dynamics of the trade balance and the terms of trade: the J-curve?", American Economic Review 84, 84-103

BAHMANI-OSKOOEE, M. (1985), "Devaluation and the J-curve: some evidence from LDCs", The Review of Economics and Statistics, 67 (3), 500-504

BAHMANI-OSKOOEE, M. and RATHA, A. (2004), “The J-curve: a literature review", Applied Economics, 36 (13), 1377-1398

BAHMANI-OSKOOEE M. and RATHA, A. (2007a), "The S-curve dynamics of US bilateral trade", Review of International Economics, 15 (2), 430-439

BAHMANI-OSKOOEE M. and RATHA, A. (2007b), "Bilateral S-curve between Japan and her trading partners", Japan and the World Economy, 19 (4), 483 489

BAHMANI-OSKOOEE M. and RATHA, A. (2008), "S-curve at the industry level: Evidence form US-UK commodity trade”, Empirical Economics, 35 (1), 141 152

BAHMANI-OSKOOEE M., GELAN and RATHA, A. (2008), "S-curve dynamics of trade in Africa", African Development Review, 20 (2), 335-342

BAHMANI-OSKOOEE M., KUTAN, A. and RATHA, A., (2008c), "The Scurve in emerging markets”, Comparative Economic Studies, 50 (2), 341-351

BAHMANI-OSKOOEE M. and RATHA, A. (2009), "S-curve dynamics of trade level: Evidence form US-Canada Commodity Trade”, Economic Issues, 14 (1), 1-16

BAHMANI-OSKOOEE M. and RATHA, A. (2010), "S-curve dynamics of trade between U.S. and China", China Economic Review, 21 (2), 121-223

BAHMANI-OSKOOEE M. and XU, J. (2010), "The S-Curve Dynamics of US-Hong Kong Commodity Trade”, Global Economic Review, 39 (2), 117-128

BAHMANI-OSKOOEE M., GELAN and RATHA, A. (2011a), "S-curve dynamics of trade between Sweden and her trading partners", Economic Systems, 35 (3), 355-362

BAHMANI-OSKOOEE M., GELAN and RATHA, A. (2011b), "S-curve at the Industry Level: Evidence from US-Australia Trade", Economic Papers, 30(4), 497-521

BAHMANI-OSKOOEE M., GELAN and RATHA, A. (2012), "ChinaGermany commodity trade and the S-curve", Journal of Chinese Economic and Foreign Trade Studies, 5(1), 20-28 
BAHMANI-OSKOOEE M. and XU, J. (2013), "The S-Curve Dynamics of US-Mexico Commodity Trade", Journal of Applied Economics, 16(1), 33-48

BAHMANI-OSKOOEE, M. and JAMILOV, R. (2013), "Export diversification and the S-curve effect in a resource-rich state: evidence from Azerbaijan", Economic Change and Restructuring, 47 (2), 1-20.

FERREIRA-LOPEZ A. and SEQUEIRA Z.N. (2014), "The Dynamic of the Trade Balance and Terms of Trade in Central and Eastern European countries", Acta Oeconomica, 64 (1), 51-71.

SENHADJI, A.S. (1998), "Dynamics of the trade balance and the terms of trade in LDCs: the S-curve", Journal of International Economics, 46 (1), 105-131 


\section{Appendix}

\section{Appendix 1. Variables}

For Turkey's terms of trade the inverse of the real effective exchange rate is used as a proxy. The calculation is made by having regard to the distinction like developed and developing countries. The real effective exchange rate for each group is calculated separately. At the bilateral level there are no terms of trade variables available. Therefore for each trading partner the inverse of the real bilateral exchange rate is calculated. The formula for this proxy is defined as ,where is the CPI in country A, is the CPI in Turkey and is the nominal exchange rate, defined as the number of A's currency per Turkish Lira. Trade balance is defined as the Turkey's net exports (X-M) relative to Turkey's GDP, both in nominal terms. All series are detrended using Hodrick-Prescott filter.

\section{Appendix 2. Sample}

The sample covers 2003Q1-2012Q4 period and it consist of 20 trading partners which play crucial role in Turkey's international trade. The sample include following countries: Germany, Russia, China, Iran, US, Italy, France, UK, Spain, Netherland, India, Switzerland, South Korea, Belgium, Saudi Arabia, Romania, Greece, Bulgaria, Israel and Japan.

\section{Appendix 3. Data Sources}

The data are collected from the following sources:

Turkish Statistical Institute: The exports, imports and GDP are collected from this source.

The Central Bank of Turkey: The exchange rate data are collected.

OECD: The CPI data are collected.

Eurostat: The CPI data for Romania and Bulgaria are collected.

Central Bank of Islamic Republic of Iran: The CPI data are collected.

Saudi Arabian Monetary Agency: The CPI data are collected.

\section{Cross-correlation coefficient}

The definition of the cross-correlation coefficient between trade balance and real exchange rate (the inverse of terms of trade) is shown as follows:

$$
C O R=\frac{\sum\left(\mathrm{REX}_{t}-R \bar{E} \mathrm{X}\right)\left(\mathrm{TB}_{t+k}-T \bar{B}\right)}{\sqrt{\sum\left(\mathrm{REX}_{t}-R \bar{E} \mathrm{X}\right)^{2}\left(T B_{t+k}-T B\right)^{2}}}
$$

and represents the mean of observations over the period 2003Q1-2012Q2. In the case of $(\mathrm{k}=0)$, contemporaneous correlation will be obtained. When $(\mathrm{k}=1)$, the 
correlation between and one period future value of trade balance is calculated. When $(\mathrm{k}=2)$ then the correlation between and two period future value of is calculated. These calculations are made in the case of a positive lag $(\mathrm{k})$. On the other hand if $(\mathrm{k})$ is negative, like $(\mathrm{k}=-1)$, it means that the correlation between and one period past value of the trade balance is calculated. By placing correlation on the vertical axis and (k) on the horizontal axis, we obtain the cross-correlation function for different positive and negative values of $(\mathrm{k})$. 